\title{
State of Small Amount of Elements in Silicon Nitride Fabricated by Post-Sintering Process Using Low-Grade Silicon Powder as Raw Materials
}

\author{
Hideki KITA, Kazuo OSUMI,* Syunkichi UENO, D. Doni JAYASEELAN and Tateoki IIZUKA* \\ National Institute of Advanced Industrial Science and Technology, 2266-98, Shimo-Shidanmi, Moriyama-ku, Nagoya-shi 463-8560 \\ *Isuzu Advanced Engineering Center, Ltd., 8, Tsuchidana, Fujisawa-shi 252-8501
}

\author{
低級ケイ素を原料として二段焼結法で作製した窒化ケイ素中の微量元素の存在状態 \\ 北＼cjkstart英紀·大角和生 $*$.上野俊吉·D. Doni Jayaseelan ·飯塚建興* \\ 産業技術総合研究所，463-8560 名古屋市守山区下志段味 2266-98 \\ *(株)いすざ中央研究所, 252-8501 藤沢市土棚 8
}

\begin{abstract}
The state of small amount of elements containing impurity in silicon nitride produced by the post sintering method from low-grade silicon powder was investigated. Iron reacted with other components in the raw materials in the sintering process to form iron silicide particles which were subsequently distributed. Most particles were as large as $2 \mu \mathrm{m}$ in diameter. Linear voids that were considered to originate in the difference of thermal expansion coefficients were observed in their perimeter. $\mathrm{Ta}_{2} \mathrm{O}_{5}$ also reacted with other elements and it was observed in the form of tantalum silicide particles. The size was few hundreds nanometer. Calcium was detected from multigrain pockets. However, not a particular particle segregation could be observed. For this reason, it is presumed that Calcium was solved into the grain-boundary phase.
\end{abstract}

[Received August 2, 2004; Accepted October 26, 2004]

Key-words : Silicon nitride, Post-sintering, Reaction-bonding, Cost, Impurity, Iron, Calcium

\section{Introduction}

Silicon nitride is a material with high strength and fracture toughness. It offers excellent thermal shock resistance and corrosion resistance. Taking advantage of such features, it is expected to be applied to engine parts and various components used in production lines for metal melting and heat treatment, such as protection tubes and heater tubes. Cost reduction, one of the most important issues to engender widespread use, requires development of technology to achieve a stable strength with pressureless sintering using inexpensive raw materials. The target price of the basic raw material is presumed to be less than $1000 \mathrm{yen} / \mathrm{kg}$, where inexpensive beta silicon nitride and low-grade silicon powder are candidates. Many studies address silicon nitride made from beta silicon nitride powder, ${ }^{1-11)}$ all of which however contain process cost increasing factors such as gas pressure sintering, HIP, hot press, or long-time mixing. The post sintering method has been also well studied, ${ }^{12)-17)}$ wherein a green body made of raw materials containing silicon and sintering aids is subjected to reaction bonding under a nitrogen atmosphere, then liquid phase sintering and densification are performed at a further elevated temperatures. Nevertheless, this kind of method which has been studied so far does not necessarily serve the goal of cost reduction because they also required the use of expensive raw materials or process such as high purity silicon powder or HIP. The authors have produced silicon nitride with a pressureless post sintering method using low purity silicon as a main raw material. Low cost raw materials contain considerable amounts of impurities and some oxides are added as catalyst, which possibly affect the properties of resultant silicon nitride. In this study, we will attempt to investigate the state of such small amount of elements in a sintered body because we considered its control to be essential to achieve stable properties.

\subsection{Specimens}

\section{Experimental procedures}

Raw materials used include $\mathrm{Si}$ (Yamaishi-Kinzoku, \#600), $\mathrm{Si}_{3} \mathrm{~N}_{4}$ (Denki-Kagaku Kogyo, SN9FW), $\mathrm{Y}_{2} \mathrm{O}_{3}$, (Nihon-Yttorium, 3N) $\mathrm{Al}_{2} \mathrm{O}_{3}$ (Syowa-Denko, UA5305), and $\mathrm{Ta}_{2} \mathrm{O}_{5}$ (Koujyundo-Kagaku, TA001PA), whose compounding ratios are $56.2,29.4,2.7,11.0$, and 0.7 (in mass \%), respectively. $\mathrm{Ta}_{2} \mathrm{O}_{5}$ was added herein for accelerating nitriding. ${ }^{14)}$ Table 1 shows the specification of the silicon used; impurities therein consist mainly of $\mathrm{Ca}$ and $\mathrm{Fe}$. The predetermined amount of each raw material powder was blended in a ball mill for $24 \mathrm{~h}$ with silicon nitride balls and ethanol. The resultant powder was dehydrated using a spray dryer, filled in a rubber mold, and subjected to cold isostatic pressing (CIP) at a pressure of $100 \mathrm{MPa}$. The green body obtained was heated up to $700^{\circ} \mathrm{C}$ for dewaxing, subjected to reaction sintering at $1400^{\circ} \mathrm{C}$ for $10 \mathrm{~h}$ under an atmospheric pressure, and sintered at a temperature up to $1850^{\circ} \mathrm{C}$ for $4 \mathrm{~h}$ in the nitrogen atmosphere under atmospheric pressure. Thus obtained SN samples provided $521 \mathrm{MPa}$ of four-point bending strength (average for thirty specimens. Weibull modulus was twenty) and $4.8 \mathrm{MPa} \cdot \mathrm{m}^{1 / 2}$ of fracture toughness $K_{1 \mathrm{c}}$.

\subsection{Evaluations}

The sintered body specimen was subjected to plasma etching treatment, and scanning electron microscopy (SEM) for microstructure observation and X-ray diffraction for material identification. Transmission electron microscopy (TEM) and energy dispersive X-ray spectroscopy (EDS) were also carried

Table 1. Specifications of the Powders Used for the Test

\begin{tabular}{|l|c|c|c|c|c|}
\hline & Average diameter & \multirow{2}{*}{$\alpha$ ratio/\% } & \multicolumn{3}{|c|}{ Impurities $/$ mass $\%$} \\
\cline { 4 - 7 } & $\mathrm{da} / \mu \mathrm{m}$ & & $\mathrm{Fe}$ & $\mathrm{Ca}$ & $\mathrm{Al}$ \\
\hline Silicon powder & 1.5 & - & 0.36 & 0.18 & 0.2 \\
\hline Silicon nitride powder & 0.75 & 91.76 & 0.028 & 0.109 & 0.086 \\
\hline
\end{tabular}



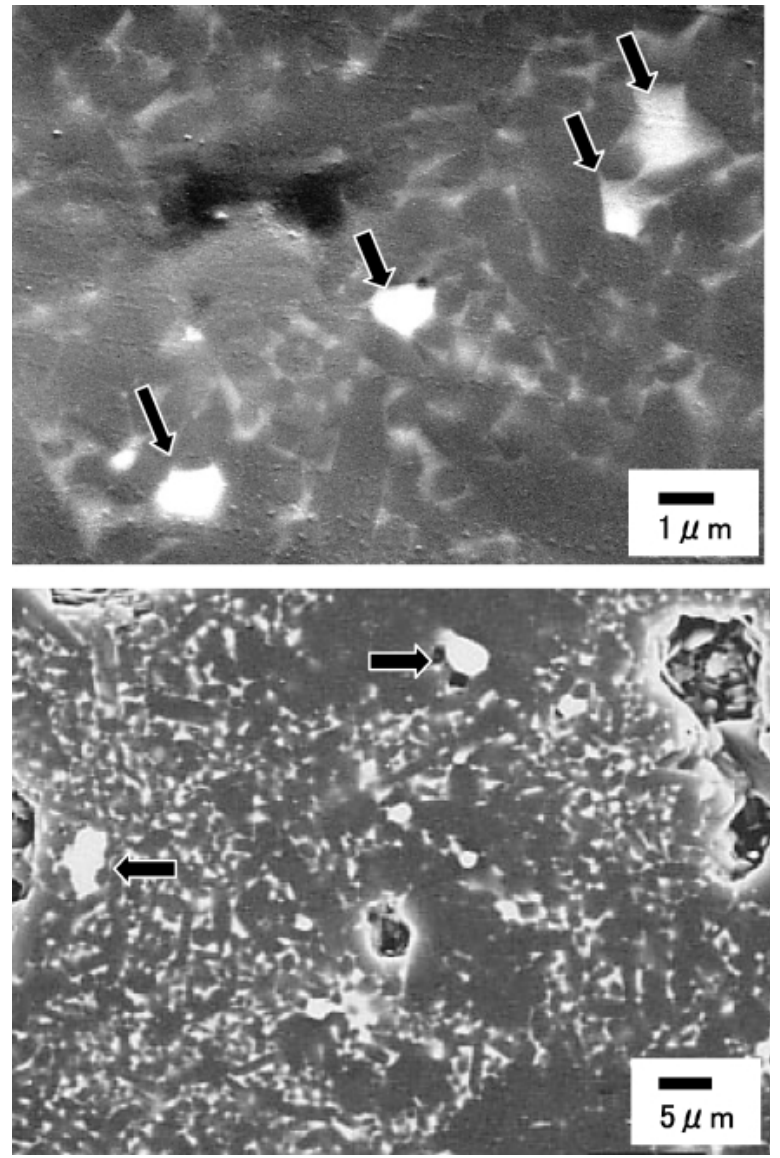

Fig. 1. SEM image of the area of vicinity of Fe-Si paricles.

out for microstructure observation and elemental analysis of resultant phases, respectively.

\section{Results and discussion}

Figure 1 shows the result of SEM observation of the specimen produced with the post sintering method. In Fig. 1, white region can be clearly observed, and from the white region that was a dispersed phase in the figure, both $\mathrm{Fe}$ and $\mathrm{Si}$ were detected. Chemical analysis ensured the high probability that the dispersed phase is $\mathrm{Fe}_{5} \mathrm{Si}_{3}$. In the $\mathrm{Fe}-\mathrm{Si}-\mathrm{N}$ ternary phase diagram, $\mathrm{Fe}_{5} \mathrm{Si}_{3}$ phase is unstable above $1600^{\circ} \mathrm{C}$, it can be assumed that $\mathrm{Fe}_{2} \mathrm{Si}$ and/or $\mathrm{FeSi}$ phases are formed at the sintering process and then these phases are decomposed into $\mathrm{Fe}_{5} \mathrm{Si}_{3}$ phase on the cooling step below $1150^{\circ} \mathrm{C}$.

Figure 2 shows a TEM photograph of the $\mathrm{Fe}_{5} \mathrm{Si}_{3}$ granular dispersed phase obtained observed in the sintered specimen. Its microstructure was further investigated: observation revealed that most particles are as large as $2 \mu \mathrm{m}$ in diameter, but that some particles are larger, of ca. $5 \mu \mathrm{m}$ diameter. The literature ${ }^{18)}$ provides the thermal expansion coefficients of $\mathrm{Fe}_{5} \mathrm{Si}_{3}$ of $17.8 \times 10^{-6} / \mathrm{K}$, which is about six times bigger than that of $\mathrm{Si}_{3} \mathrm{~N}_{4} . \mathrm{Fe}_{5} \mathrm{Si}_{3}$, formed as a liquid phase in the sintering process, then cooled and solidified, shrinks markedly compared with $\mathrm{Si}_{3} \mathrm{~N}_{4}$ particles, which mainly constitute the matrix. That shrinkage is attributable to the difference in the thermal expansion coefficients. Therefore, it was anticipated that great residual stress occurred or that a microstructure change took place when stress accompanied by shrinkage was released by crack initiation. The white linear regions in the perimeter of $\mathrm{Fe}_{5} \mathrm{Si}_{3}$ particles are voids in the figure. The voids do not

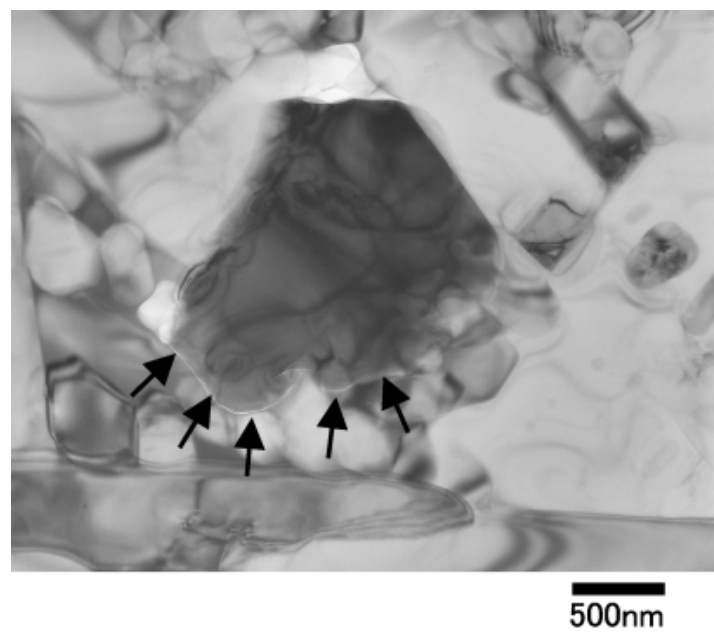

Fig. 2. TEM image of vicinity of Fe-Si paricle.

envelop a whole $\mathrm{Fe}_{5} \mathrm{Si}_{3}$ particle completely; rather, $\mathrm{Fe}_{5} \mathrm{Si}_{3}$ particles are partially bound to the matrix. The magnified view of this photograph indicated $10-25 \mathrm{~nm}$ of the interval of linear voids. The size of voids formed between two phases because of the difference in thermal expansion coefficients was computed with a simplified computation. It was assumed that a dispersed phase $\mathrm{Fe}_{5} \mathrm{Si}_{3}$ formed a liquid phase at sintering, then cooled from $1000^{\circ} \mathrm{C}$ and solidified into the observed microstructure. The product of the diameter of $\mathrm{Fe}_{5} \mathrm{Si}_{3}$ granular dispersed phase in Fig. 2, $2 \mu \mathrm{m}$, and the difference of the thermal expansion coefficients and temperatures between the matrix and the dispersed phase yielded the void width computed as about $20 \mathrm{~nm}$. That void width nearly matched the observation result. The possibility that the voids observed in Fig. 2 may have occurred at specimen preparation does not allow us to conclude directly that they were generated by the thermal expansion coefficient difference. Nevertheless, it is very likely because such a situation was observed for many particles. It is desirable that the void size be further reduced to relieve stress concentration towards high and stable strength.

Other elements such as Ta, $\mathrm{Ca}, \mathrm{Al}, \mathrm{Y}$ were hard to observe by SEM approach. Figure 3 summarizes the EDS analysis results for the particular sites within the TEM observation field. The numbers in the TEM photograph shown at the top denote the analysis positions, designated as Points 1-4 in the result table, respectively.

Ta was detected from point 2 , and from this dark region, both $\mathrm{Ta}$, Si and very few amount of oxygen were detected, suggesting tantalum silicide formation. Chemical analysis ensured the high probability that tantalum silicide can be confirmed in the sintered sample as shown in Fig. 3, although tantalum oxide $\mathrm{Ta}_{2} \mathrm{O}_{5}$ is stable in nitrogen atmosphere at high temperature. Because carbon crucible was used in the present study, it can be assumed that $\mathrm{Ta}_{2} \mathrm{O}_{5}$ reduced by carbo-thermally reductions and the reduced tantalum atom react with silicon nitride and then, tantalum silicide was formed at the sintering temperatures.

The microstructure of the bound region between $\mathrm{Si}_{3} \mathrm{~N}_{4}$ particles in the matrix was observed with TEM, as shown in Fig. 4. Calcium atom as impurity of silicon and/or silicon nitride powders localized only on the triple point of the boundary, namely, calcium atom segregated from the normal boundary on the sintering process. The EDS analysis result indicated that $\mathrm{Si}, \mathrm{Al}, \mathrm{Y}$, and $\mathrm{O}$ were detected from the boun- 


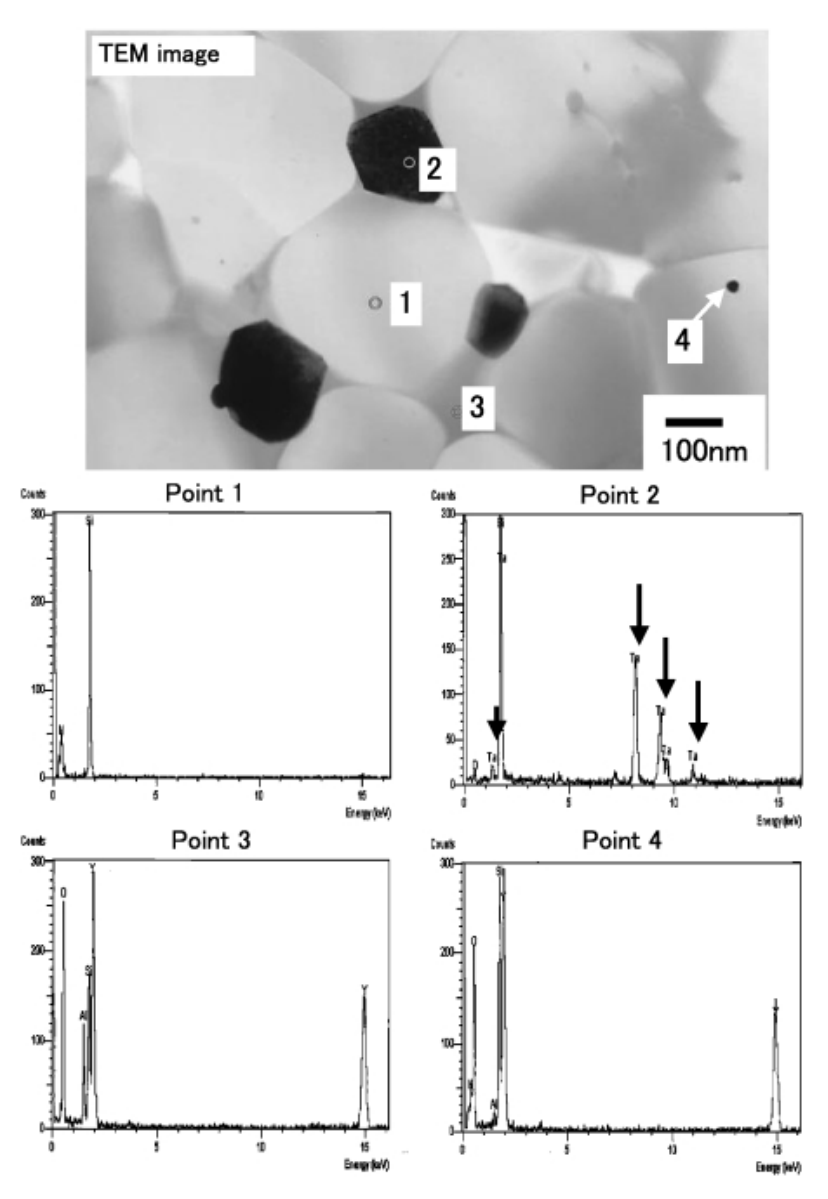

Fig. 3. TEM image of the specified area and the EDS analysis results.

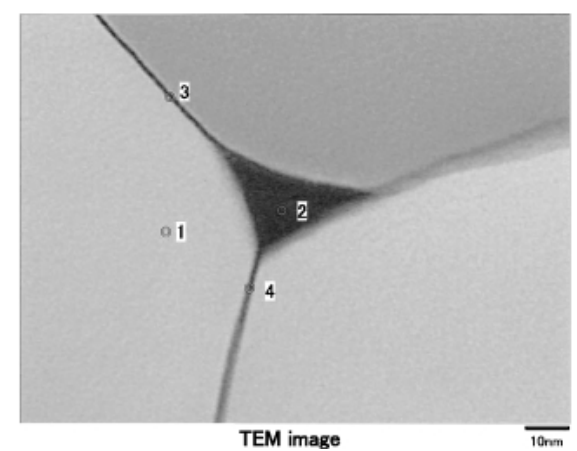

Fig. 4. TEM image of grain (1), grain pocket (2) and grain boundary $(3,4)$ of tested sample.

dary layers, similar with the components of the glassy phase observed in common silicon nitride sintered bodies. The results was summarized in Fig. 5. Soni et al. also observed the grain boundary segregation of $\mathrm{Mg}$ and $\mathrm{Ca}$ atom insintered alumina phase. ${ }^{19)}$ They suggested that the principal role of $\mathrm{MgO}$ and $\mathrm{CaO}$ are to reduce the grain boundary mobility via a solute-drag model. In the present case, it can be assumed that $\mathrm{CaO}$ and $\mathrm{Al}_{2} \mathrm{O}_{3}$ coexist at the boundary during the sintering process and then on the cooling step, $\mathrm{CaO}$ segregated from the liquid phase which consisted of the boundary according to the same mechanism of the segregation by solute-drag model.

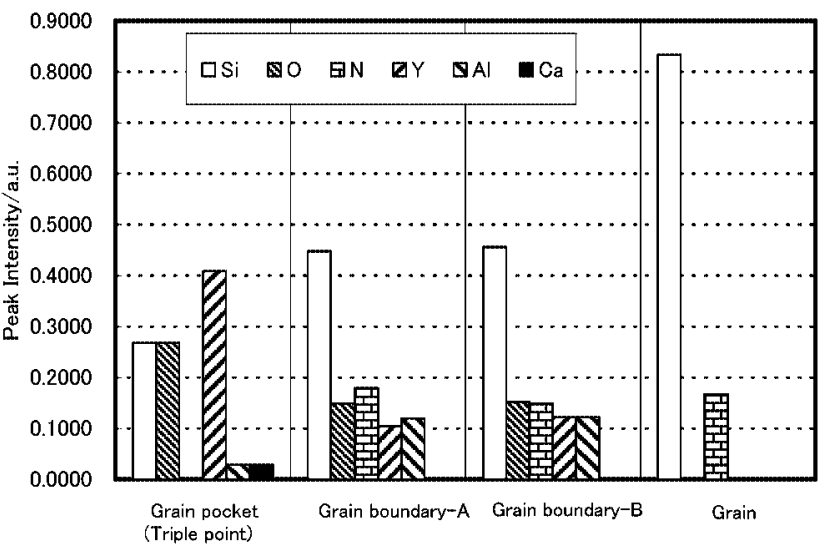

Fig. 5. EDS analysis results on grain, grain pocket and grain boundary of tested sample.

\section{Conclusions}

We conducted this study with the aim of clarifying the state of small amount of elements containing impurity and trace elements in silicon nitride produced by the post sintering method from low-grade raw materials, to acquire the following knowledge:

(1) Iron reacted with other components in the raw materials in the sintering process to form $\mathrm{Fe}-\mathrm{Si}$ particles which were subsequently distributed. Most particles were as large as $2 \mu \mathrm{m}$ in diameter, but some particles were larger, with diameter of ca. $5 \mu \mathrm{m}$.

(2) Linear voids that were considered to originate in the difference of thermal expansion coefficients were observed in their perimeter.

(3) $\mathrm{Ta}_{2} \mathrm{O}_{5}$ also reacted with other elements and observed in the form of $\mathrm{Ta}-\mathrm{Si}$ particles. The size was few hundreds nanometer.

(4) Calcium was detected from grain pockets. However, no particular particle containing it was observed. For that reason, it is presumed to be solved into the grain-boundary phase.

Acknowledgements This work was supported by NEDO, as apart of the Synergy Ceramics Project promoted by METI, Japan. Some of the authors were the members the Joint Research Consortium of the Synergy Ceramics.

\section{References}

1) Hirotsuru, H., Mitomo, M. and Nishimura, T., J. Ceram. Soc. Japan, Vol. 103, pp. 464-469 (1995) [in Japanese].

2) Hirosaki, N., Ando, M., Akimune, Y. and Mitomo, M., J. Ceram. Soc. Japan, Vol. 100, pp. 826-829 (1992) [in Japanese].

3) Hirosaki, N., Ando, M., Akimune, Y. and Mitomo, M., J. Ceram. Soc. Japan, Vol. 100, pp. 1366-1370 (1992) [in Japanese].

4) Hirosaki, N., Okamoto, Y., Akimune, Y. and Mitomo, M., $J$. Ceram. Soc. Japan, Vol. 102, pp. 790-794 (1994) [in Japanese].

5) Hirosaki, N., Okamoto, Y., Akimune, Y. and Mitomo, M., J. Ceram. Soc. Japan, Vol. 102, pp. 790-794 (1994) [in Japanese].

6) Hirotsuru, H., Mitomo, M. and Nishimura, T., J. Ceram. Soc. Japan, Vol. 104, pp. 23-27 (1996) [in Japanese].

7) Hirosaki, N., Okamoto, Y., Akimune, Y., Yamada, T. and Mitomo, M., J. Ceram. Soc. Japan, Vol. 103, pp. 977-978 (1995) [in Japanese].

8) Emoto, H., Hirotsuru, H. and Mitomo, M., J. Ceram. Soc. 
Japan, Vol. 106, pp. 488-493 (1998) [in Japanese].

9) Hirosaki, N., Akimune, Y. and Mitomo, M., J. Ceram. Soc. Japan, Vol. 101, pp. 1239-1243 (1993) [in Japanese].

10) Hirano, T., Yang, J. and Niihara, K., J. Ceram. Soc. Japan, Vol. 104, pp. 348-353 (1996) [in Japanese].

11) Mitomo, M., Tsutsumi, M. and Tanaka, H., J. Am. Ceram. Soc., Vol. 73, pp. 2441-2445 (1990).

12) Zhuang, H. R., Li, W. L., Hua, D. Q., Wen, S. L., Sun, Y. Y. $\mathrm{Fu}, \mathrm{X}$. R. and Yen, T. S., Proc. of International Symposium Ceramic Components for Engine, pp. 368-372 (1983).

13) Giachello, A. and Popper, P., Ceramurgia International, Vol. 5, n. 3, 1979, pp. 110-114 (1979).

14) Yamada, T., Suzuki, S. and Ohsumi, K., 6th International Symposium on Ceramic Materials and Engine Components for
Engine, pp. 613-616 (1997).

15) Braue, E., Goring, J., Heinrich, J., Steiner, M., Kruner, H. and Riedel, G., 6th International Symposium on Ceramic Materials and Engine Components for Engine, pp. 161-166 (1997).

16) Ziegler, G. and Heinrich, J., J. Mater. Science, Vol. 22, pp. 3041-3086 (1987).

17) Riley, F. L., Material Science Forum, Vol. 47, pp. 70-83 (1989).

18) Camcohob, B., "Databook Koyuten Kagobutsu Binran," Nissotusin-sha (1976) pp. 215-215 [in Japanese].

19) Soni, K. K., Thompson, A. M., Harmer, M. P., Williams, D. B., Chabala, J. M. and Setti, R. L., Appl. Phys. Lett., Vol. 66, pp. 2795-2797 (1995). 